\title{
Pectus excavatum - cosmetic problem or something more?
}

\section{(D) Petra Angebrandt*, (D)Dejan Došen, \\ (D) Maja Hrabak, \\ (D)Eduard Margetić, \\ (DIrena Ivanac Vranešić}

University of Zagreb School of Medicine, University Hospital Centre Zagreb, Zagreb, Croatia

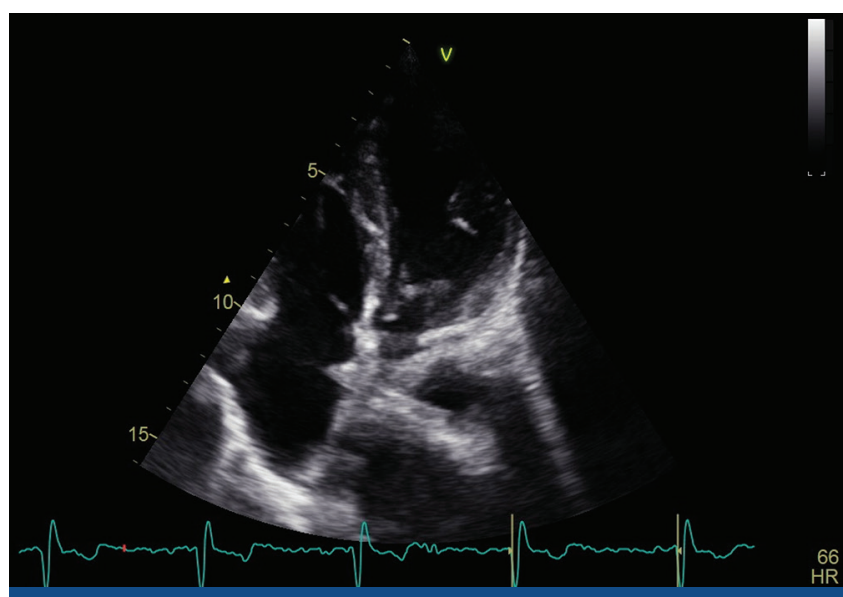

FIGURE 1. Apical four chamber view of extra cardiac mass compressing left atrium.

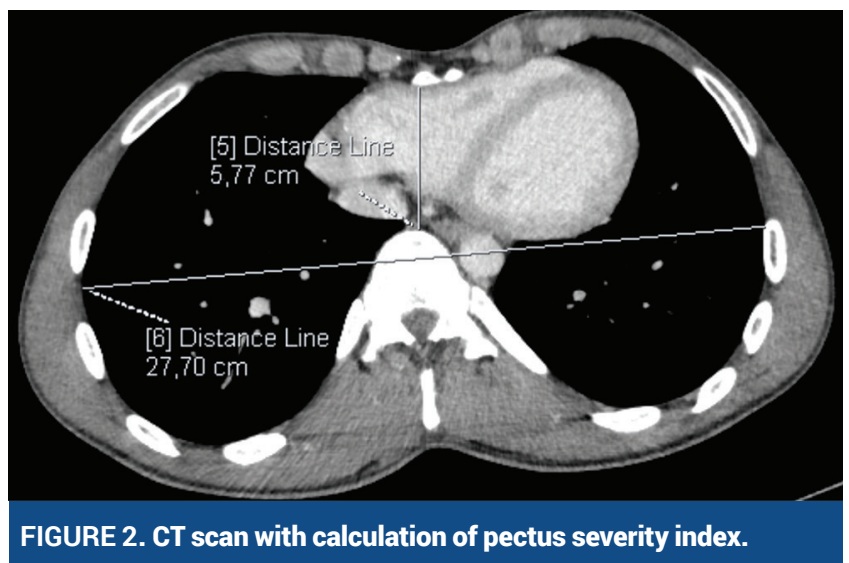

RECEIVED:

February 28, 2019

ACCEPTED:

March 24, 2019

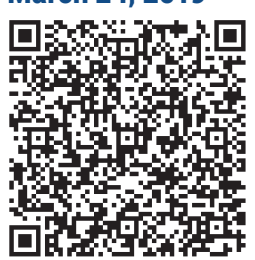

KEYWORDS: pectus excavatum, cardiac CT, cardiac mass.

CITATION: Cardiol Croat. 2019;14(3-4):46. | https://doi.org/10.15836/ccar2019.46

*ADDRESS FOR CORRESPONDENCE: Petra Angebrandt, Klinički bolnički centar Zagreb, Kišpatićeva 12, HR-10000 Zagreb, Croatia. / Phone: +385-91-1596-814 / E-mail: petraang37@yahoo.com

ORCID: Petra Angebrandt, https://orcid.org/0000-0001-5431-9736 • Dejan Došen, https://orcid.org/0000-0002-2641-4768 Maja Hrabak, https://orcid.org/0000-0002-0390-8466 • Eduard Margetić, https://orcid.org/0000-0001-9224-363X Irena Ivanac Vranešić, https://orcid.org/0000-0002-6910-9720

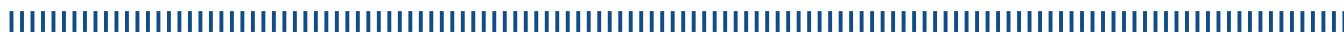

Introduction: Pectus excavatum, a deformity of the sternum and ribs caused by an unbalanced costochondral hypertrophy, is a congenital abnormality with a prevalence of $1 / 1000$ and it is commonly considered to be an incidental finding without clinical significance. In more advanced cases there may be a considerable compression and relocation of thoracic organs which can lead to serious cardiac or respiratory symptoms. ${ }^{1-3}$

Case report: 19-year-old male patient was admitted for two-month history of palpitations, shortness of breath and continuous chest pain. Physical exam showed significant pectus excavatum and thoracic lordosis with otherwise normal findings. Resting 12-lead ECG and laboratory tests were normal, including cardiac troponin T levels. 24-hour ECG revealed premature ventricular beats with a paroxysm of non-sustained ventricular tachycardia. Echocardiography (Figure 1) showed normal biventricular size and function and raised suspicion of a large tumor mass compressing the left atrium (LA). No obvious signs of flow obstruction in LA using color and spectral Doppler were noticed. Mitral valve showed billowing of the anterior leaflet with otherwise normal valve function. The next diagnostic step was thoracic CT scan (Figure 2) which revealed extremely thin sagittal thoracic diameter with vertebrae compressing posterior wall of the LA and no signs of a tumor mass. Exercise stress test showed normal functional capacity with no signs of ischemia or arrhythmias in ECG. Patient was started on minimal dose of bisoprolol and follow up 24-hour ECG showed no ventricular arrhythmias. Since CT scan is the gold standard for determining the severity of the pectus excavatum defect, pectus severity index (PSI) was calculated and in our patient the value was 4.8. A normal chest has an average PSI of 2.5 and patients with a PSI of $>3.25$ are considered candidates for surgery. Patient was scheduled for additional respiratory function tests and will be referred to thoracic surgeon

Conclusion: Severe cases of pectus excavatum can have significant impact on cardiorespiratory function and in those patients, surgery should be considered. On echocardiography, LA compression by vertebrae can even mimic a tumor mass but thoracic CT scan is a gold standard for diagnostic and severity assessment of this condition.

$\square$ Cardiologia Croatica 2019;14(3-4):46.

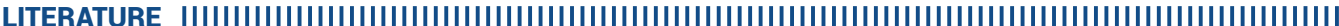

1. Winkens $\mathrm{R}$, Guldemond $\mathrm{F}$, Hoppener $\mathrm{P}$, Kragten $\mathrm{H}$, van Leeuwen Y. Pectus excavatum, not always as harmless as it seems. BMJ Case Rep. 2009;2009. pii: bcr10.2009.2329. https://doi.org/10.1136/bcr.10.2009.2329

2. Goretsky MJ, Kelly RE Jr, Croitoru D, Nuss D. Chest wall anomalies: pectus excavatum and pectus carinatum. Adolesc Med Clin. 2004 Oct;15(3):455-71. https://doi.org/10.1016/j.admecli.2004.06.002

3. Mansour KA, Thourani VH, Odessey EA, Durham MM, Miller JI Jr, Miller DL. Thirty-year experience with repair of pectus deformities in adults. Ann Thorac Surg. 2003 Aug;76(2):391-5; discussion 395. https://doi.org/10.1016/S0003-4975(03)00441-7 